Int. J. Electrochem. Sci., 13 (2018) $8471-8480$

International Journal of

ELECTROCHEMICAL

SCIENCE

www.electrochemsci.org

\title{
The Determination of Human Albumin by a Quartz Crystal Microbalance Immunosensor
}

\author{
Miroslav Pohanka \\ Faculty of Military Health Sciences, University of Defence, Trebesska 1575, CZ-500 01 Hradec \\ Kralove \\ E-mail: miroslav.pohanka@gmail.com
}

doi: $10.20964 / 2018.09 .14$

Received: 2 April 2018 / Accepted: 25 May 2018 / Published: 5 August 2018

\begin{abstract}
Albumin is a protein serving as a standard biochemical marker which is assayed in the blood and blood plasma as a liver function test but its diagnostics importance is much wider. In the current time, albumin can be determined by standard immunochemical and spectral methods. In this work, immunosensor based on the piezoelectric $10 \mathrm{MHz}$ QCM was developed to determine albumin in levels corresponding with expected concentration in blood plasma. The immunosensor contained an antibody specific to albumin interdigitated to electrode surface through protein A. The immunosensor was performed for the determination of albumin and limit of detection $0.234 \mathrm{mg} / \mathrm{ml}$ was achieved. The limit of detection is lower than the expected plasma level of albumin $(35-55 \mathrm{mg} / \mathrm{ml})$. The immunosensor assay fully correlated with the standard ELISA and the immunosensor exerted good long-term stability for at least two months. The immunosensor based determination of albumin appears to be a promising tool for practical use in field or home care conditions. No elaborative manipulation with samples or necessity to use specific reagents is a significant advantage of the immunosensor based assay.
\end{abstract}

Keywords: affinity; albumin; antibody; biosensor; biorecognition; immunochemistry; label free assay; liver function test; piezoelectric; quartz crystal microbalance

\section{FULL TEXT}

(C) 2018 The Authors. Published by ESG (www.electrochemsci.org). This article is an open access article distributed under the terms and conditions of the Creative Commons Attribution license (http://creativecommons.org/licenses/by/4.0/). 